\title{
REVIEW
}

\section{Current perspectives on the pathogenesis of clinically non-functioning pituitary tumours}

\author{
N J L Gittoes \\ Department of Medicine, Queen Elizabeth Hospital, Edgbaston, Birmingham B15 2TH, UK
}

\section{Introduction}

Pituitary tumours are classified by the characteristic clinical syndromes that accompany tumour hormone production. All of the constituent hormone-secreting cell types of the anterior pituitary are capable of undergoing neoplastic change, although it is evident from histochemical analysis that adenomas derived from pure, functional lactotrophs, corticotrophs, somatotrophs, gonadotrophs and thyrotrophs are the exception rather than the rule. Tumours frequently express more than one hormone (Scheithauer et al. 1986, Kovacs \& Horvath 1988), most frequently growth hormone $(\mathrm{GH})$ and prolactin (PRL), although immunohistochemical detection of hormones is not a marker of true secretory function. Pituitary tumours that secrete intact hormones result in clinical syndromes of hormone hypersecretion - PRL causing clinical features of hyperprolactinaemia, GH causing acromegaly or gigantism, adrenocorticotrophic hormone $(\mathrm{ACTH})$ causing Cushing's disease and thyroid-stimulating hormone (TSH) causing secondary hyperthyroidism. Approximately $25-30 \%$ of all anterior pituitary neoplasms, however, do not cause clinical syndromes of hormone hypersecretion and are termed non-functioning tumours (NFTs).

The term non-functioning is strictly a clinical term, as it is now clear from the results of immunohistochemistry that the majority of these tumours do indeed synthesise, and sometimes secrete, hormones (Arafah 1986), predominantly subunits of the glycoprotein hormones (GPHs; luteinizing hormone $(\mathrm{LH})$, follicle-stimulating hormone (FSH) and TSH) or, occasionally, intact GPHs (Snyder et al. 1979, 1984, Snyder 1985, Black et al. 1987, Jameson et al. 1987, Klibanski 1987, Warnet et al. 1994). Figure 1 shows typical immunostaining properties of an NFT.

\section{Tumour characterisation}

The application of the technique of immunohistochemistry has revolutionised the classification of pituitary tumours in terms of their hormone expression. It has also become apparent, however, that the clinical entity of NFT encompasses a marked heterogeneity of neoplastic pituitary cell types. By histopathological convention, NFTs are sometimes subdivided into pure null cell adenomas (17\%) and oncocytomas (6\%; Thapar et al. 1995). The distinction is purely morphological, and relates to the intracellular accumulation of mitochondria in oncocytomas to greater than $10 \%$ of the cell volume. There is evidence of non-neoplastic null cells scattered throughout the normal pituitary cytoarchitecture (Kovacs et al. 1980, Kontogeorgos et al. 1991) that probably represent transitional, undifferentiated or precursor cells, capable of shifting from a hormonally inactive resting state to a hormonally active differentiated state. Null cell adenomas may therefore be envisaged as neoplastic derivatives of such cells. No clinical or prognostic differences exist between null cell adenomas and oncocytomas.

'Silent' corticotroph adenomas represent a subcategory of clinically non-functioning tumours and account for up to $8 \%$ of NFTs (Kovacs 1985). These tumours have emerged as distinct clinicopathological entities (Horvath et al. 1980, 1988), but bear striking morphological and immunohistochemical resemblance to hormonally active corticotroph adenomas. They are not, however, accompanied by clinical or biochemical evidence of ACTH excess. Silent somatotroph adenomas have also been described (Warnet et al. 1994) and exhibit positive immunostaining for $\mathrm{GH}$, but result in no clinical features of acromegaly. These tumours account for approximately $3 \%$ of all NFTs (Kovacs 1985).

In vitro studies have demonstrated expression of intact gonadotrophins or subunits of these GPHs in approximately $80 \%$ of NFTs (Samuels \& Ridgway 1995). Pure $\alpha$-subunit secreting pituitary adenomas have also been recognised, and represent approximately $7 \%$ of all NFTs (Snyder 1985). In view of the propensity of NFTs to express gonadotrophin subunits, the cell type of origin of these tumours is likely to be gonadotrophs in the majority of cases.

\section{Pathogenesis}

The pathogenesis of NFTs, like the majority of other pituitary tumour types, remains elusive. The potential 

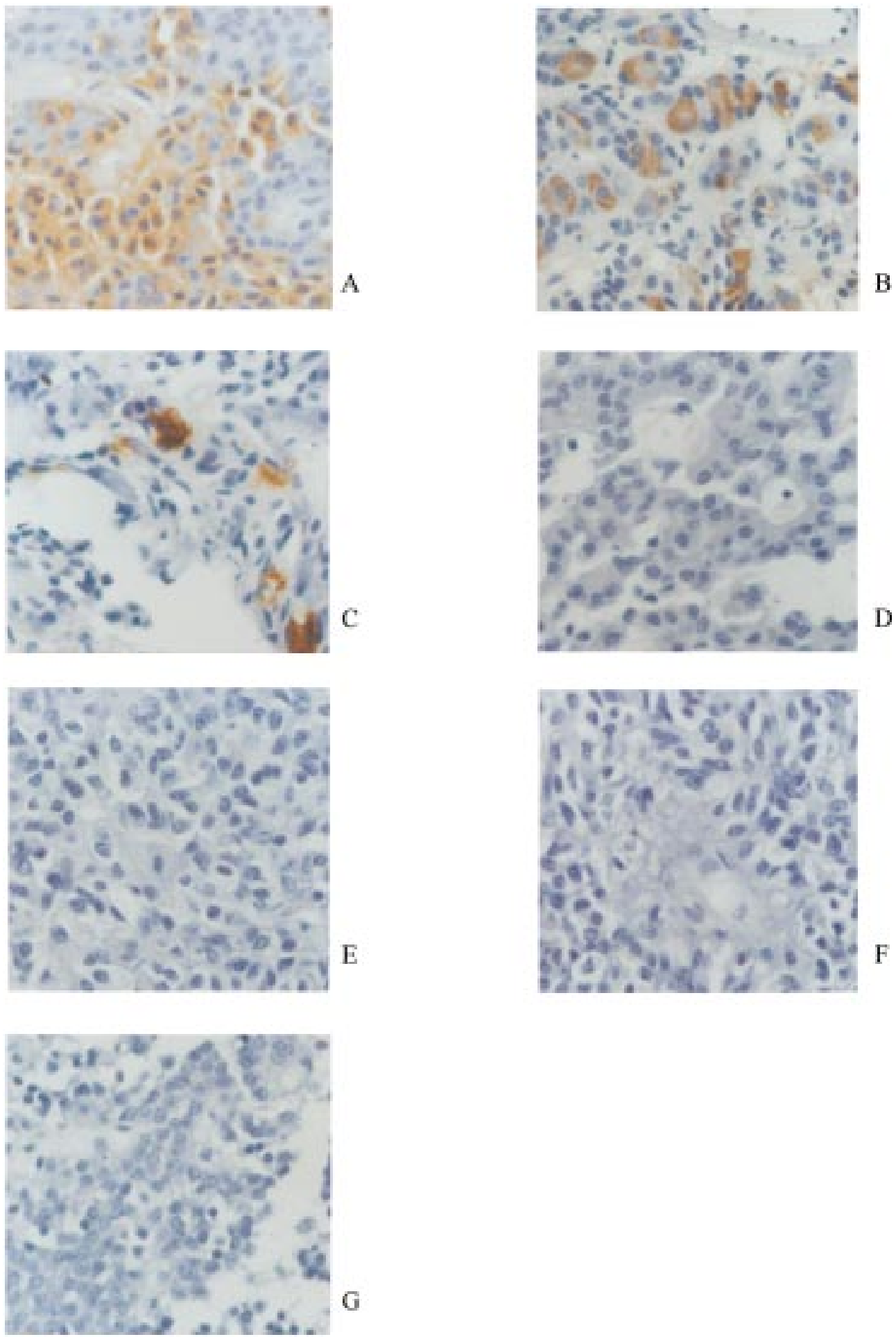

Figure 1 Typical immunostaining characteristics for anterior pituitary hormone expression in an NFT. Brown cytoplasmic colouration represents positive immunostaining. Panels $\mathrm{A}-\mathrm{D}$ show results for $\mathrm{GPH}$ subunits (A, common $\alpha$-subunit; $\mathrm{B}, \mathrm{FSH} \beta ; \mathrm{C}, \mathrm{LH} \beta ; \mathrm{D}, \mathrm{TSH} \beta$ ). Negative (blue) immunostaining is noted for other anterior pituitary hormones (E, ACTH; F, GH; G, prolactin). 


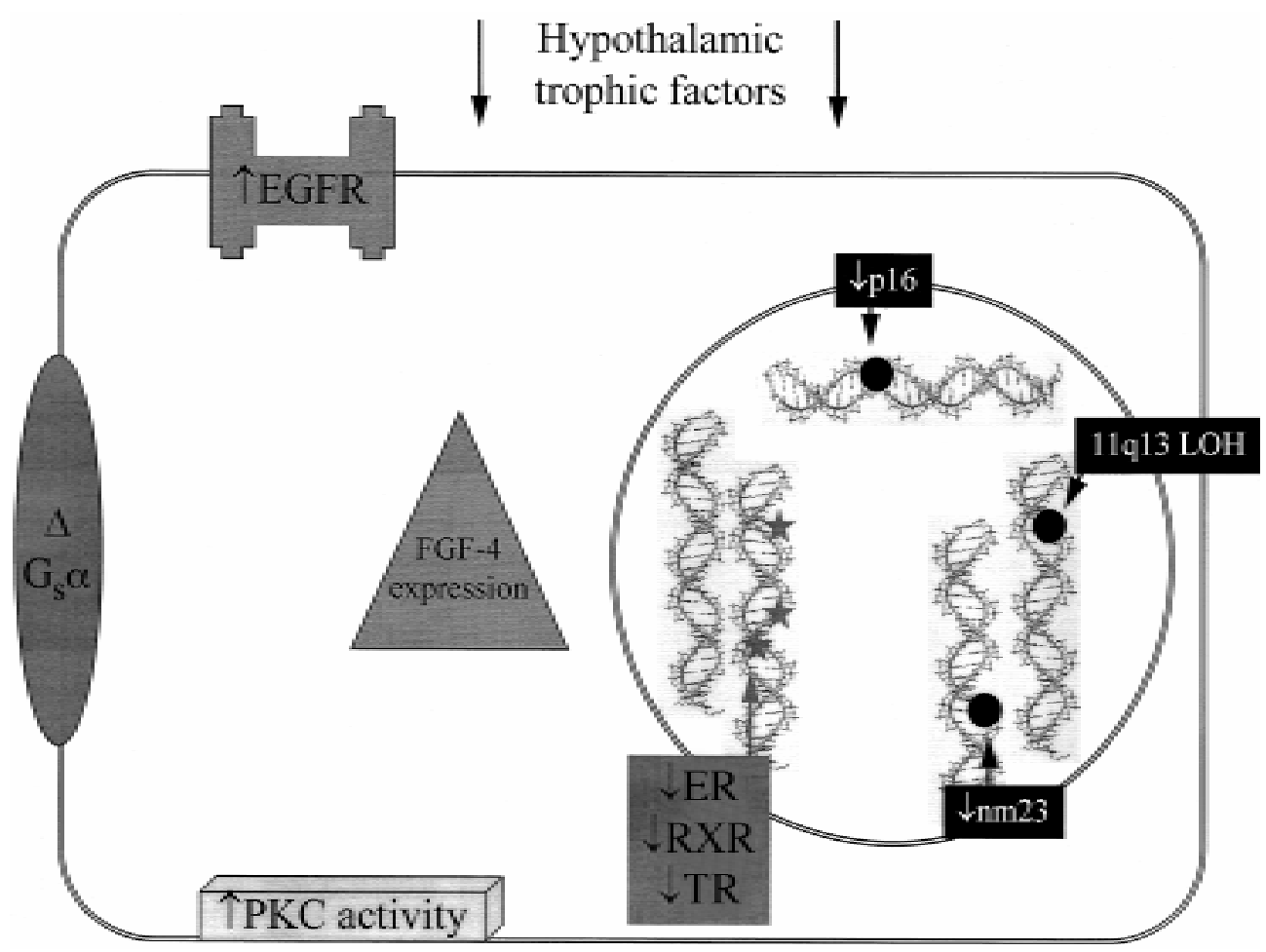

Figure 2 Diagrammatic representation of possible aetiological factors involved in the genesis of NFTs. EGFR, epidermal growth factor receptor; $\mathrm{LOH}$, loss of heterozygosity; ER, oestrogen receptor; RXR, retinoid X receptor; TR, thyroid hormone receptor; FGF, fibroblast growth factor; PKC, pyruvate kinase C.

mechanisms of oncogenesis can, however, be grouped into broad categories. Abnormalities of genes regulating growth and hormone secretions may be implicated, abnormalities of tumour suppressor genes that normally inhibit growth and proliferation may also be involved in tumorigenesis, as may alterations in genes involved in the induction of apoptosis. Figure 2 provides a summary of the possible aetiological factors that may be important in the development of NFTs.

\section{Influence of hypothalamic trophic hormones on tumorigenesis}

Hypothalamic releasing factors evoke specific hormonal responses in anterior pituitary cells, but also affect pituitary cell proliferation (Asa et al. 1984b, 1992, Wehrenberg et al. 1984, Gertz et al. 1987, Cella et al. 1990, Burton et al. 1991, Struthers et al. 1991, Stenzel-Poore et al. 1992). In this way, disordered hypothalamic control has been implicated in the aetiology of pituitary adenomas (reviewed by Faglia \& Spada (1995)). The feedback tumour that rarely develops in patients with congenital adrenal hyperplasia (an ACTH-secreting pituitary tumour arising secondary to the absence of normal negative feedback effect of cortisol on ACTH secretion) provides evidence that unopposed hypothalamic stimulation can lead to tumour progression, although there are a number of factors against a primary hypothalamic defect being the initiating step in pituitary tumorigenesis. Hyperplasia of somatotrophs or corticotrophs surrounding an adenoma is rarely seen in acromegaly and Cushing's disease, implying a more focal origin of the tumours as opposed to the release of a generalised trophic factor (Molitch 1987). Patients with an ectopic source of GH-releasing hormone hypersecretion (secondary to bronchial carcinoids, small cell lung carcinomas and pancreatic islet cell tumours) exhibit consequent somatotroph hyperplasia and $\mathrm{GH}$ hypersecretion, but rarely develop true somatotroph adenoma formation (Sano et al. 1988). Similarly, patients with Cushing's syndrome secondary to ectopic CRH hypersecretion do not develop corticotroph adenomas (Asa et al. 1984a, Carey et al. 1984). Furthermore, surgical resection of functioning pituitary tumours results in a definitive cure of excess hormone secretion in a significant proportion of tumours. These observations strongly suggest that pituitary adenomas are derived from an intrinsic defect of a single progenitor cell, leading to tumour formation, rather than from excessive polyclonal expansion of cells as a result of hypersecretion of hypothalamic trophic factors. Despite the unlikely role of hypothalamic factors in initiating the majority of pituitary tumours, it is likely that progression of tumour formation in a susceptible subtype of pituitary cells may be due to hypothalamic dysregulation (Faglia \& Spada 1995). 

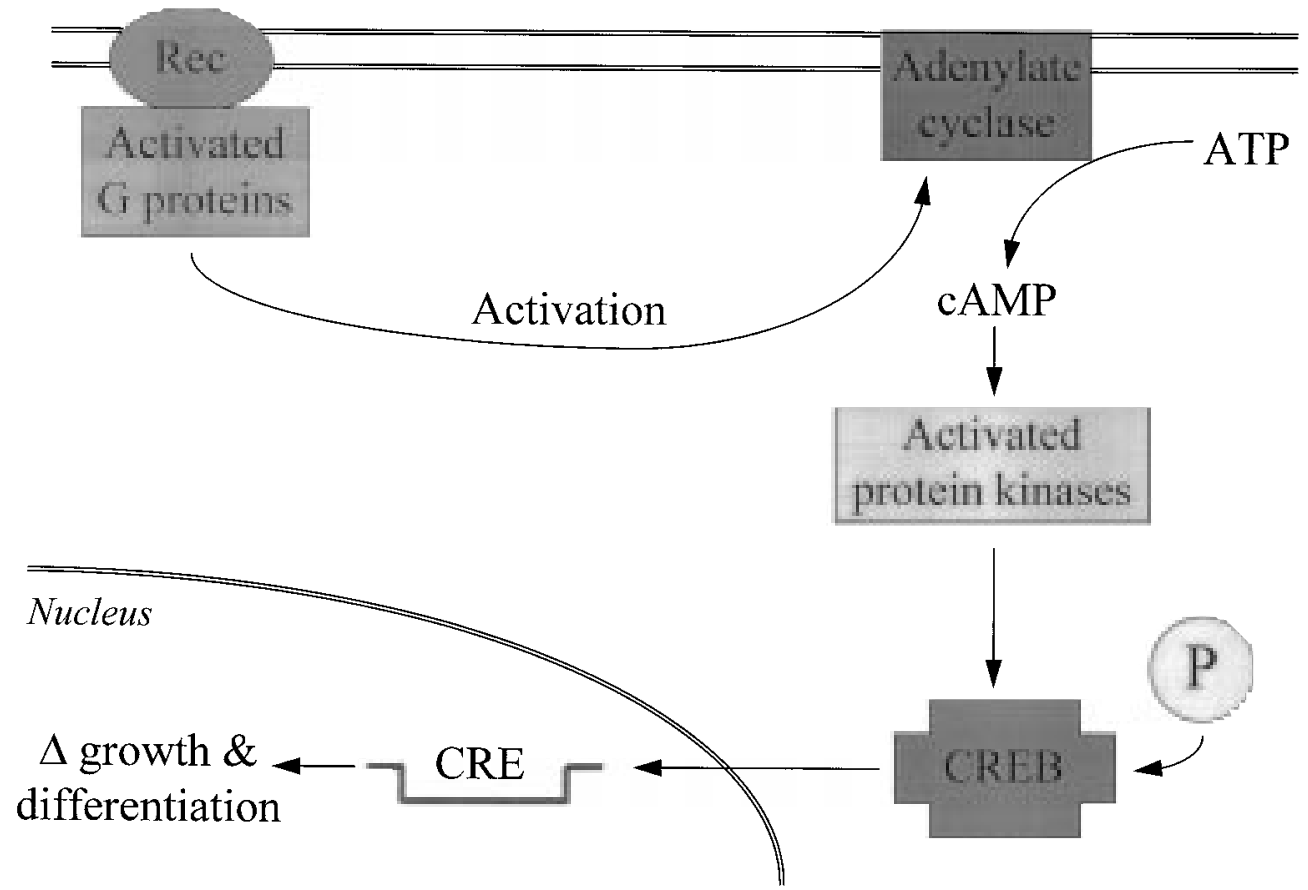

Figure 3 Diagrammatic representation of the cAMP signalling cascade. Receptor (Rec) occupation results in activation of coupled G proteins, which serve to activate adenylate cyclase, causing conversion of ATP to CAMP. Activated cAMP-dependent protein kinases phosphorylate CAMP response element binding protein (CREB) which translocates to the nucleus and, via occupation of CAMP response elements (CRE), regulates transcription of genes involved in cellular growth and differentiation.

\section{Activating genetic mutations}

Clonality studies have revealed that, like the majority of pituitary tumour types, NFTs are monoclonal in origin (Alexander et al. 1990, Herman et al. 1990). Search for rearrangements or mutations of known candidate oncogenes in NFTs has largely been unfruitful, however. Of a total of 68 NFTs examined for oncogene $(m y c, r a s, b c l$, Hst1, sea and fos) amplifications or rearrangements, none was found to harbour these anomalies (Karga et al. 1992, Herman et al. 1993, Boggild et al. 1994). Mutations of the gene encoding the $\alpha$-subunit of the membrane-bound stimulatory GTP-binding protein $\left(\mathrm{G}_{\mathrm{s}} \alpha\right)$ transduction molecule (Lyons et al. 1990), more commonly associated with a subgroup of $\mathrm{GH}$-secreting pituitary adenomas (Spada et al. 1990, Masters et al. 1990), have been described in approximately 10\% of NFTs (Tordjman et al. 1993, Williamson et al. 1994). Mutations in the gene encoding $\mathrm{G}_{\mathrm{s}} \alpha$ result in formation of the $g s p$ oncogene, a constitutively active form of $G_{s} \alpha$ that results in unabated activation of adenylyl cyclase, increased cyclic AMP (cAMP) generation, increased intracellular calcium and activation of cAMP-dependent protein kinases leading to phosphorylation of the cAMP response element-binding protein (CREB), which mediates the transcriptional effects of cAMP (Fig. 3). This signalling pathway transduces messages that dictate cellular growth and differentiation, and thus changes in the intrinsic activity of this mechanism result in enhanced proliferative capacity of tumour cells. Interestingly, Bertherat et al. (1995) have demonstrated increased concentrations of activated CREB in all GH-secreting tumours (compared with concentrations in NFTs), irrespective of the presence of the gsp oncogene. This finding suggests that mechanisms other than gsp mutations can lead to constitutive activation of CREB and thus to tumour formation.

\section{Abnormal signal transduction pathways}

The trophic effects of factors derived from the hypothalamus are mediated in cells of the anterior pituitary by cell surface receptors that are differentially expressed in a cell-type-specific pattern. A number of studies have looked for evidence of mutated cell surface receptors for hypothalamic releasing or inhibitory factors in pituitary tumours. As a result of the observation that a proportion of NFTs respond to administration of a bolus of thyrotrophin-releasing hormone $(\mathrm{TRH})$ by a brisk increase in GPH subunit secretion (MacFarlane et al. 1982, Snyder 1985, Daneshdoost et al. 1991), the TRH receptor gene has been investigated for evidence of mutations. Of seven NFTs examined, none was found to harbour TRH receptor mutations (Faccenda et al. 1996). The dopamine 
type 2 receptor gene has also been analysed in a series of NFTs and no mutations were detected (Friedman et al. 1994). Differential expression of somatostatin receptor subtypes has been demonstrated in NFTs, although no consistent pattern of subtype expression has been determined (Greenman \& Melmed 1994, Miller et al. 1995, Panetta \& Patel 1995, Murabe et al. 1996).

The membrane-bound protein kinase C (PKC) enzyme family regulates many cellular processes, including cell proliferation and differentiation, via serine or threonine phosphorylation of substrate proteins. Increased levels of expression and enhanced activity of PKC have been detected in NFTs compared with the findings in normal pituitaries (Alvaro et al. 1992). Furthermore, invasive tumours demonstrated higher levels of expression of PKC than did non-invasive tumours (Alvaro et al. 1992), suggesting a possible role for this important growth regulating enzyme in the genesis of NFTs and other pituitary adenomas.

Activins are members of the transforming growth factor- $\beta$ (TGF $\beta$ ) cytokine family that act as pituitary cell mitogens and as modulators of hormone biosynthesis via cell surface receptors with transmembrane serine/ threonine kinase activity (Mathews 1994). In vitro, exogenous activin has been shown to regulate pituitary cell proliferation (Billestrup et al. 1990, Bilezikjian et al. 1991), but, in addition, endogenous activin subunit expression has been demonstrated in pituitary adenomas (Haddad et al. 1994, Alexander et al. 1995), raising the possibility of an autocrine action for these growth factors. Alexander et al. (1996) determined the expression of activin/TGF $\beta$ receptor subtype mRNAs in a series of pituitary adenomas, including nine NFTs and normal pituitaries. There was a difference in the pattern of activin/TGF $\beta$ receptor expression between normal glands and tumours that may convey a growth advantage upon pituitary tumour cells.

\section{Growth factors in pituitary tumorigenesis}

The effects of many growth factors, including insulin like growth factor-I (IGF-I), fibroblast growth factor (FGF), platelet-derived growth factor (PDGF) and epidermal growth factor (EGF) have been implicated in many human neoplasms (Zumkeller \& Schofield 1995). The cellular effects of growth factors are mediated by high-affinity receptor tyrosine kinases that share a common intracellular signalling pathway. Ligand binding to the extracellular domain of this class of receptor results in activation of a cascade of downstream signalling molecules. Autophosphorylation of the liganded receptor results in recruitment of adapter proteins such as Grb2, which in turn serve to activate the guanine-nucleotide exchange factors sos, ras, mitogen activated protein (MAP) kinase kinase kinase, MAP kinase kinase, MAP kinase and, ultimately, the nuclear transcription factors jun and fos (Fig. 4). Growth factor receptors may also influence gene transcription via a more direct route. After ligand binding, the tyrosine kinase receptors can activate specific cytoplasmic proteins, which translocate to the nucleus and mediate transcriptional regulation (Montminy 1993). From the preceding description, it can be seen that a number of intermediary elements are involved in transducing the effects of growth factors, and abnormalities within any element of the activating cascade may be responsible for constitutive activation and unabated cell growth. Experimentally derived mutants of MAP kinase kinase have been shown to exhibit such constitutive activity (Mansour et al. 1994). Furthermore, the MAP kinase signal transduction pathway has also been shown to regulate the expression of the GPH common $\alpha$-subunit (Roberson et al. 1995) and the specific FSH $\beta$-subunit in vitro (Strahl et al. 1997), findings that may be pertinent to the frequent observation of GPH subunit expression in NFTs (Samuels \& Ridgway 1995).

EGF and EGF receptor (EGFR) expression have been studied in a series of pituitary adenomas, and overexpression of EGFR was detected in 80\% of NFTs examined, although EGFR was virtually undetectable in all functioning pituitary tumours (Chaidarun et al. 1994a). The response of tumour cells in vitro to EGF administration was also examined and showed accelerated tumour growth and up-regulation of EGFR mRNA expression (Chaidarun et al. 1994a), implicating a role for EGF and its receptor in the development, progression, or both, of NFTs.

FGF-4 (or heparin-binding secretory transforming gene, hst) is normally expressed exclusively in embryonic tissues, although it has been detected in a number of human neoplasms (Sakamoto et al. 1986). hst transfected rat pituitary cells have aggressive and invasive characteristics when injected subcutaneously (Shimon et al. 1996) and the observation of frequent expression of $h s t$ in prolactinomas suggests that it has a significant role in the pathogenesis of PRL-secreting adenomas (Gonsky et al. 1991). The gene product of hst has also been detected in 5\% of other pituitary tumours, including NFTs (unpublished data in Shimon \& Melmed 1997), suggesting a possible aetiological role of hst in a minority of NFTs.

\section{Tumour suppressor genes}

Much attention has focused on the importance of the role of tumour suppressor genes in down-regulating cellular growth. Tumour suppressor gene abnormalities promote neoplasia through loss of function of a protein normally involved in restricting cell growth. They usually act in a recessive manner and require that both alleles must be mutated (usually in the form of a gross chromosomal deletion) for the transformed phenotype to be fully expressed. Studies of loss of heterozygosity have demonstrated allelic deletions on chromosome $11 \mathrm{q} 13$ in $20 \%$ of NFTs (Boggild et al. 1994), indicating the possibility of a

Journal of Endocrinology (1998) 157, 177-186 


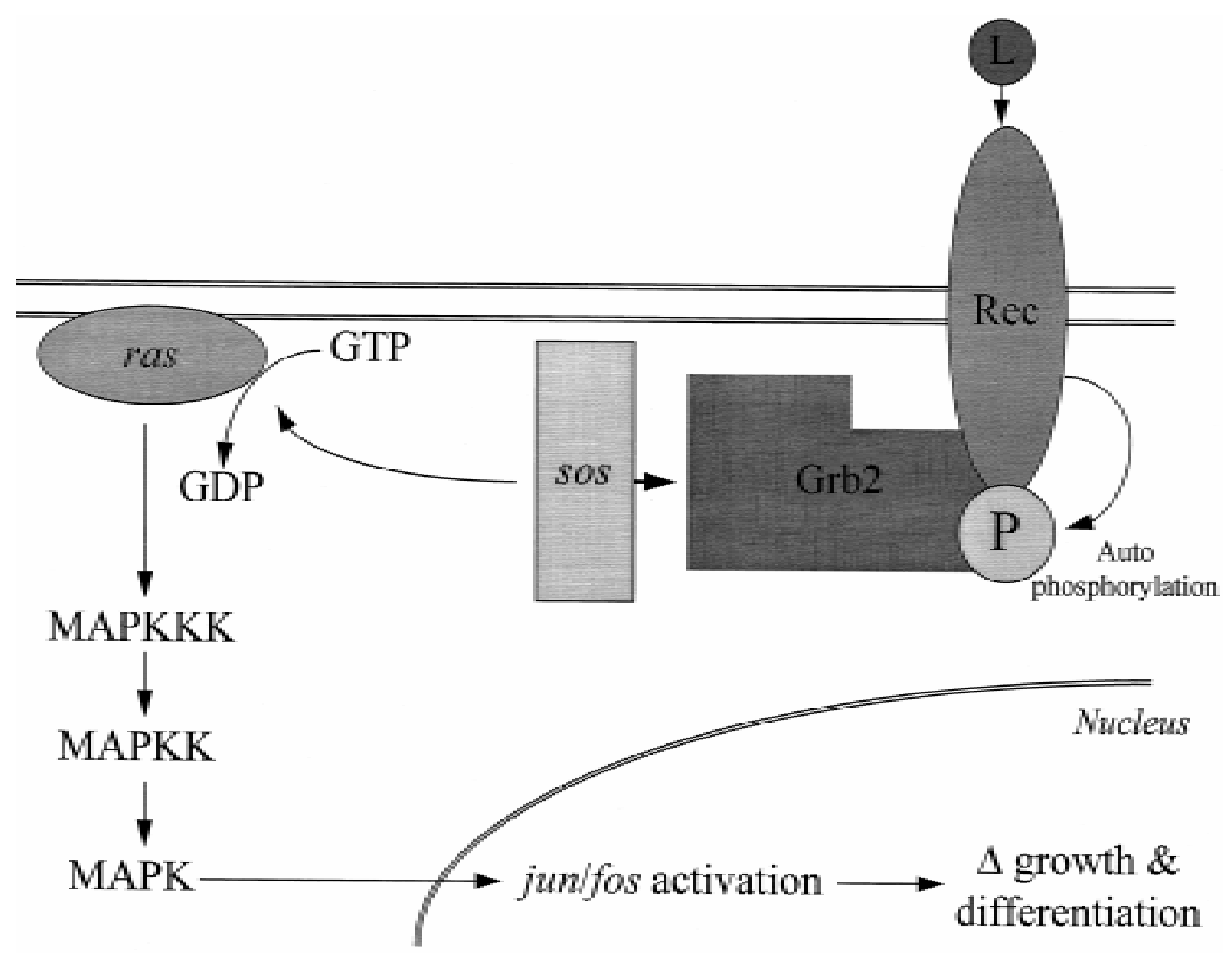

Figure 4 Diagrammatic representation of the MAP kinase signal transduction pathway. Receptor (Rec) autophosphorylation (P) occurs upon ligand (L) binding. Recruitment of Grb2 and sos results in activation of ras and perpetuation of the cascade of MAP kinases (MAPK), ultimately causing activation of the transcription factors jun and fos, which serve to regulate important cellular activities, including growth and differentiation.

recessively acting tumour suppressor gene in this region. The recently cloned gene for multiple endocrine neoplasia (MEN)-type 1 has been found to reside at this chromosomal location (Chandrasekharappa et al. 1997), hence the so-called 'menin' gene product is also a likely candidate in the pathogenesis of sporadic pituitary tumours. Mutations of the $p 53$ tumour suppressor gene are common events in many human cancers (Hollstein et al. 1991, 1996), although in three series with a total of 186 pituitary tumours investigated, including 72 NFTs, no $p 53$ gene mutations were detected (Herman et al. 1993, Levy et al. 1994, Boggild et al. 1994).

The retinoblastoma $(\mathrm{Rb})$ gene has been the focus of much attention as a candidate for pituitary tumorigenesis via loss of heterozygosity. The $\mathrm{Rb}$ gene product has important regulatory properties in the cell cycle, controlling differentiation and survival. Homozygous inactivation of the $\mathrm{Rb}$ alleles results in the formation of retinoblastomas, and loss of heterozygosity of the $\mathrm{Rb}$ gene in mice results in pro-opiomelanocortin-expressing pituitary tumours (Jacks et al. 1992, Hu et al. 1994). Search for loss of heterozygosity in the chromosomal region (13q) of the $\mathrm{Rb}$ gene in human pituitary tumours (secretory and non-secretory) has revealed interesting results. One group identified no loss of either Rb allele (Woloschak et al. 1994), although other groups have detected loss of heterozygosity in the region of the Rb gene (Pei et al. 1995, Pearce et al. 1996). Further studies revealed, however, that $\mathrm{Rb}$ protein was detectable by immunohistochemistry in those tumours with loss of heterozygosity on chromosome 13, indicating that a novel (non-Rb) candidate tumour suppressor gene may be present at this location (Pei et al. 1995).

Cyclin-dependent kinase (CDK) inhibitors have a pivotal role in controlling cell cycle progression. CDK4 phosphorylates the product of the $\mathrm{Rb}$ gene which results in inactivation of its ability to regulate the cell cycle (Weinberg 1995). The complexity of this system is further enhanced by the presence of a specific inhibitor of CDK4, p16. p16 acts to maintain the integrity and function of the $\mathrm{Rb}$ protein, but has been detected at lower levels in some pituitary tumours, including 14 NFTs (Woloschak et al. 1996), than in normal pituitaries. Although no structural abnormalities of the p16 gene or loss of heterozygosity at its chromosomal location have been identified, p16 remains of possible aetiological significance in pituitary tumorigenesis. 
The so-called metastasising suppressor gene, $\mathrm{nm} 23$, is a purine binding factor that has been detected in reduced quantities in highly metastatic cancers (Bevilacqua et al. 1989). nm23 expression has been determined in a number of pituitary tumours, including ten NFTs (Takino et al. 1995). Reduced expression of the $\mathrm{H} 2$ isoform mRNA and protein was detected in invasive tumours and there was an inverse correlation between nm 23 mRNA concentrations and the tendency for cavernous sinus invasion. There was no evidence of mutations in the nm23 gene in any of the invasive tumours, however.

\section{Abnormal expression of nuclear steroid/thyroid hormone receptors}

Although mutations leading to altered expression of oncogene or tumour suppressor gene products may have a pathogenic role in NFTs, a change in hormonal regulation of pituitary gene expression may contribute to uncontrolled tumour cell proliferation. Recently, a number of reports of abnormal expression of nuclear steroid/ thyroid hormone receptors have been described in NFTs. We have documented reduced expression of isoforms of thyroid hormone receptors and retinoid $\mathrm{X}$ receptors in NFTs (Gittoes et al. 1997a,b) compared with the findings in normal pituitaries. Absent, or reduced, expression of oestrogen receptor $(\alpha)$ protein has also been demonstrated in NFTs (Nakao et al. 1989, Friend et al. 1994, Stefaneanu et al. 1994, Zafar et al. 1995, Gittoes et al. 1997a). The latter observation is of particular relevance, as NFTs are believed to be derived from cells of the gonadotroph lineage and thus would be expected to express oestrogen receptor (Friend et al. 1994, Zafar et al. 1995). Reduced expression of oestrogen receptor in this cell type may therefore be expected to mediate inadequate negative feedback, perhaps leading to autonomous secretory and growth characteristics. Recently, tumour-specific expression of oestrogen receptor mRNA splice variants has been described in some NFTs and other pituitary tumours (Chaidarun et al. 1997).

The functional significance of abnormalities of nuclear steroid/thyroid hormone receptor expression is not as yet determined, although the ligands for these receptors (for example thyroid hormone, retinoic acid and oestrogens) are known to be important regulators of growth and development in various tissues, including the pituitary (Shupnik et al. 1989, Lloyd et al. 1991, Koga et al. 1992, Chomczynski et al. 1993, Chaidarun et al. 1994b, Weiss \& Refetoff 1996). Abnormal expression of nuclear steroid/ thyroid hormone receptors in NFTs may therefore be expected to influence the growth pattern, and thus the overall biological behaviour of these tumours.

\section{Pituitary tumour transforming genes}

Recently, a potent transforming gene has been isolated from a rat GH-secreting pituitary tumour cell line, designated pituitary tumour-transforming gene (PTTG; Pei \& Melmed 1997). PTTG is not expressed in normal pituitaries but when over-exposed in $3 \mathrm{~T} 3$ fibroblasts, induces cellular transformation in vitro. Injection of transfected $3 \mathrm{~T} 3$ cells into athymic nude mice also results in rapid formation of tumours. It remains to be determined whether this gene or related genes have a pathogenic role in human pituitary tumours.

\section{Summary and future research directions}

The heterogeneity of pituitary tumour subtypes that are clinically manifest as NFTs, makes it highly unlikely that there is a single common aetiological event. Multiple molecular events, possibly acting independently, or more probably synergistically, are likely to be necessary for tumour initiation and progression (illustrated in Fig. 2). Early events in tumorigenesis are likely to involve chromosomal mutations, resulting perhaps in oncogene activation or loss of tumour suppressor genes. Subsequently, permissive factors, such as aberrant hypothalamic hormone receptor signals and dysregulated control of growth and differentiation, are likely to be important in allowing clonal expansion of the transformed pituitary cell.

In view of the probable multifactorial nature of pituitary tumorigenesis, the scope of future research is likely to remain diverse. In terms of initiating events in tumorigenesis, however, considerable interest will focus upon the recently characterised gene responsible for MEN-type 1 (Chandrasekharappa et al. 1997). A significant proportion of sporadic pituitary tumours harbour loss of heterozygosity of chromosome 11q13 (Boggild et al. 1994), and it is therefore likely that loss of this gene product (menin, which bears no apparent sequence homology with any previously described proteins) has a crucial role in sporadic pituitary tumorigenesis. An alternative strategy, recently successfully applied by Pei \& Melmed (1997) to isolate the PTTG gene from a rat GH-secreting cell line, involves differential display RT-PCR to delineate pituitary tumour-specific genes. This approach is appealing with respect to human pituitary tumours, although the cellular heterogeneity often observed in pituitary adenomas significantly reduces the feasibility of this approach.

To determine the pathogenesis of NFTs, it may be pertinent to elucidate a characteristic feature of this tumour type, such as GPH subunit expression. Expression of GPH subunits is known to be regulated by gonadal steroids and thyroid hormone, and our own work has shown that receptors for these ligands are present in reduced quantities in NFTs (Gittoes et al. 1997a). For the future, it will be interesting to investigate the effects of transfecting these receptors into primary cultures of NFTs to determine whether there is any significant change in tumour growth or secretory capacity. The MAP kinase signal transduction pathway has also been shown to be

Journal of Endocrinology (1998) 157, 177-186 
involved in transcriptional regulation of GPH subunits (Roberson et al. 1995, Strahl et al. 1997). To date there has been no 'systematic' analysis of this pathway in NFTs, and abnormalities along this complex chain of intermediaries may therefore be involved in altered GPH synthesis and, possibly, cellular growth.

\section{References}

Alexander JM, Biller BM, Bikkal H, Zervas NT, Arnold A \& Klibanski A 1990 Clinically nonfunctioning pituitary tumors are monoclonal in origin. Journal of Clinical Investigation 86 336-340.

Alexander JM, Swearingen B, Tindall GT \& Klibanski A 1995 Human pituitary adenomas express endogenous inhibin subunit and follistatin messenger ribonucleic acids. Journal of Clinical Endocrinology and Metabolism 80 147-152.

Alexander JM, Bikkal HA, Zervas NT, Laws E Jr \& Klibanski A 1996 Tumor-specific expression and alternate splicing of messenger ribonucleic acid encoding activin/transforming growth factor-beta receptors in human pituitary adenomas. Journal of Clinical Endocrinology and Metabolism 81 783-790.

Alvaro V, Touraine P, Raisman Vozari R, Bai-Grenier F, Birman P \& Joubert D 1992 Protein kinase C activity and expression in normal and adenomatous human pituitaries. International Journal of Cancer 50 724-730.

Arafah BM 1986 Reversible hypopituitarism in patients with large nonfunctioning pituitary adenomas. Journal of Clinical Endocrinology and Metabolism 62 1173-1179.

Asa SL, Kovacs K, Tindall GT, Barrow DL, Horvath E \& Vecsei P $1984 a$ Cushing's disease associated with an intrasellar gangliocytoma producing corticotrophin-releasing factor. Annals of Internal Medicine 101 789-793.

Asa SL, Scheithauer BW, Bilbao JM, Horvath E, Ryan N, Kovacs K, Randall RV, Laws E Jr, Singer W \& Linfoot JA $1984 b$ A case for hypothalamic acromegaly: a clinicopathological study of six patients with hypothalamic gangliocytomas producing growth hormone-releasing factor. Journal of Clinical Endocrinology and Metabolism 58 796-803.

Asa SL, Kovacs K, Hammer GD, Liu B, Roos BA \& Low MJ 1992 Pituitary corticotroph hyperplasia in rats implanted with a medullary thyroid carcinoma cell line transfected with a corticotropin-releasing hormone complementary deoxyribonucleic acid expression vector. Endocrinology 131 715-720.

Bertherat J, Chanson P \& Montminy M 1995 The cyclic adenosine $3^{\prime}, 5^{\prime}$-monophosphate-responsive factor CREB is constitutively activated in human somatotroph adenomas. Molecular Endocrinology 9 777-783.

Bevilacqua G, Sobel ME, Liotta LA \& Steeg PS 1989 Association of low nm23 RNA levels in human primary infiltrating ductal breast carcinomas with lymph node involvement and other histopathological indicators of high metastatic potential. Cancer Research 49 5185-5190.

Bilezikjian LM, Blount AL, Campen CA, Gonzalez-Manchon C \& Vale W 1991 Activin-A inhibits proopiomelanocortin messenger RNA accumulation and adrenocorticotropin secretion of AtT20 cells. Molecular Endocrinology 5 1389-1395.

Billestrup N, Gonzalez-Manchon C, Potter E \& Vale W 1990 Inhibition of somatotroph growth and growth hormone biosynthesis by activin in vitro. Molecular Endocrinology 4 356-362.

Black PM, Hsu DW, Klibanski A, Kliman B, Jameson JL, Ridgway EC, Hedley-Whyte ET \& Zervas NT 1987 Hormone production in clinically nonfunctioning pituitary adenomas. Journal of Neurosurgery 66 244-250.

Boggild MD, Jenkinson S, Pistorello M, Boscaro M, Scanarini M, McTernan P, Perrett CW, Thakker RV \& Clayton RN 1994
Molecular genetic studies of sporadic pituitary tumors. Journal of Clinical Endocrinology and Metabolism 78 387-392.

Burton FH, Hasel KW, Bloom FE \& Sutcliffe JG 1991 Pituitary hyperplasia and gigantism in mice caused by a cholera toxin transgene. Nature 350 74-77.

Carey RM, Varma SK, Drake C Jr, Thorner MO, Kovacs K, Rivier J \& Vale W 1984 Ectopic secretion of corticotropin-releasing factor as a cause of Cushing's syndrome. A clinical, morphologic, and biochemical study. New England Journal of Medicine 311 13-20.

Cella SG, Locatelli V, Mennini T, Zanini A, Bendotti C, Forloni GL, Fumagalli G, Arce VM, de Gennaro Colonna V \& Wehrenberg WB 1990 Deprivation of growth hormone-releasing hormone early in the rat's neonatal life permanently affects somatotropic function. Endocrinology 127 1625-1634.

Chaidarun SS, Eggo MC, Sheppard MC \& Stewart PM 1994a Expression of epidermal growth factor (EGF), its receptor, and related oncoprotein (erbB-2) in human pituitary tumors and response to EGF in vitro. Endocrinology 135 2012-2021.

Chaidarun SS, Eggo MC, Stewart PM, Barber PC \& Sheppard MC $1994 b$ Role of growth factors and estrogen as modulators of growth, differentiation, and expression of gonadotropin subunit genes in primary cultured sheep pituitary cells. Endocrinology 134 935-944.

Chaidarun SS, Klibanski A \& Alexander JM 1997 Tumor-specific expression of alternatively spliced estrogen receptor messenger ribonucleic acid variants in human pituitary adenomas. Journal of Clinical Endocrinology and Metabolism 82 1058-1065.

Chandrasekharappa SC, Guru SC, Manickam P, Olufemi SE, Collins FS, Emmert-Buck MR, Debelenko LV, Zhuang Z, Lubensky IA, Liotta LA, Crabtree JS, Wang Y, Roe BA, Weisemann J, Boguski MS, Agarwal SK, Kester MB, Kim YS, Heppner C, Dong Q, Spiegel AM, Burns AL \& Marx SJ 1997 Positional cloning of the gene for multiple endocrine neoplasia-type 1. Science 276 404-407.

Chomczynski P, Soszynski PA \& Frohman LA 1993 Stimulatory effect of thyroid hormone on growth hormone gene expression in a human pituitary cell line. Journal of Clinical Endocrinology and Metabolism 77 281-285.

Daneshdoost L, Gennarelli TA, Bashey HM, Savino PJ, Sergott RC, Bosley TM \& Snyder PJ 1991 Recognition of gonadotroph adenomas in women [see comments]. New England Journal of Medicine 324 589-594.

Faccenda E, Melmed S, Bevan JS \& Eidne KA 1996 Structure of the thyrotrophin-releasing hormone receptor in human pituitary adenomas. Clinical Endocrinology 44 341-347.

Faglia G \& Spada A 1995 The role of the hypothalamus in pituitary neoplasia. Baillières Clinical Endocrinology and Metabolism 9 225-242 (Review).

Friedman E, Adams EF, Hoog A, Gejman PV, Carson E, Larsson C, De Marco L, Werner S, Fahlbusch R \& Nordenskjold M 1994 Normal structural dopamine type 2 receptor gene in prolactinsecreting and other pituitary tumors. Journal of Clinical Endocrinology and Metabolism 78 568-574.

Friend KE, Chiou YK, Lopes MB, Laws E Jr, Hughes KM \& Shupnik MA 1994 Estrogen receptor expression in human pituitary: correlation with immunohistochemistry in normal tissue, and immunohistochemistry and morphology in macroadenomas. Journal of Clinical Endocrinology and Metabolism 78 1497-1504.

Gertz BJ, Contreras LN, McComb DJ, Kovacs K, Tyrrell JB \& Dallman MF 1987 Chronic administration of corticotropin-releasing factor increases pituitary corticotroph number. Endocrinology 120 381-388.

Gittoes NJL, McCabe CJ, Verhaeg J, Sheppard MC \& Franklyn JA 1997a Thyroid hormone and estrogen receptor expression in normal pituitary and 'non-functioning' tumors of the anterior pituitary. Journal of Clinical Endocrinology and Metabolism 82 1960-1967.

Gittoes NJL, McCabe CJ, Verhaeg J, Sheppard MC \& Franklyn JA $1997 b$ Retinoid X receptor expression in the normal pituitary and clinically non-functioning pituitary tumours. Clinical Endocrinology (In Press) 
Gonsky R, Herman V, Melmed S \& Fagin J 1991 Transforming DNA sequences present in human prolactin-secreting pituitary tumors. Molecular Endocrinology 5 1687-1695.

Greenman Y \& Melmed S 1994 Expression of three somatostatin receptor subtypes in pituitary adenomas: evidence for preferential SSTR 5 expression in the mammosomatotroph lineage. Journal of Clinical Endocrinology and Metabolism 79 724-729.

Haddad G, Penabad JL, Bashey HM, Asa SL, Gennarelli TA, Cirullo R \& Snyder PJ 1994 Expression of activin/inhibin subunit messenger ribonucleic acids by gonadotroph adenomas. Journal of Clinical Endocrinology and Metabolism 79 1399-1403.

Herman V, Fagin J, Gonsky R, Kovacs K \& Melmed S 1990 Clonal origin of pituitary adenomas. Journal of Clinical Endocrinology and Metabolism 71 1427-1433.

Herman V, Drazin NZ, Gonsky R \& Melmed S 1993 Molecular screening of pituitary adenomas for gene mutations and rearrangements. Journal of Clinical Endocrinology and Metabolism 77 $50-55$.

Hollstein M, Sidransky D, Vogelstein B \& Harris CC 1991 p53 mutations in human cancers. Science 253 49-53 (Review).

Hollstein M, Shomer B, Greenblatt M, Soussi T, Hovig E, Montesano R \& Harris CC 1996 Somatic point mutations in the p53 gene of human tumors and cell lines: updated compilation. Nucleic Acids Research 24 141-146.

Horvath E, Kovacs K, Killinger DW, Smyth HS, Platts ME \& Singer W 1980 Silent corticotropic adenomas of the human pituitary gland: a histologic, immunocytologic, and ultrastructural study. American Journal of Pathology 98 617-638.

Horvath E, Kovacs K, Smyth HS, Killinger DW, Scheithauer BW, Randall R, Laws E Jr \& Singer W 1988 A novel type of pituitary adenoma: morphological features and clinical correlations. Journal of Clinical Endocrinology and Metabolism 66 1111-1118.

Hu N, Gutsmann A, Herbert DC, Bradley A, Lee WH \& Lee EY 1994 Heterozygous Rb-1 delta 20/+mice are predisposed to tumors of the pituitary gland with a nearly complete penetrance. Oncogene 9 1021-1027.

Jacks T, Fazeli A, Schmitt EM, Bronson RT, Goodell MA \& Weinberg RA 1992 Effects of an Rb mutation in the mouse [see comments]. Nature 359 295-300.

Jameson JL, Klibanski A, Black PM, Zervas NT, Lindell CM, Hsu DW, Ridgway EC \& Habener JF 1987 Glycoprotein hormone genes are expressed in clinically nonfunctioning pituitary adenomas. Journal of Clinical Investigation 80 1472-1478.

Karga HJ, Alexander JM, Hedley-Whyte ET, Klibanski A \& Jameson JL 1992 Ras mutations in human pituitary tumors. Journal of Clinical Endocrinology and Metabolism 74 914-919.

Klibanski A 1987 Nonsecreting pituitary tumors. Endocrinology and Metabolism Clinics of North America 16 793-804 (Review).

Koga M, Nakao H \& Sato B 1992 Effects of retinoic acid on estrogen- and thyroid hormone-induced growth in a newly established rat pituitary tumor cell line. Journal of Steroid Biochemistry and Molecular Biology 43 263-270.

Kontogeorgos G, Horvath E, Kovacs K, Killinger DW \& Smyth HS 1991 Null cell adenoma of the pituitary with features of plurihormonality and plurimorphous differentiation. Archives of Pathology and Laboratory Medicine 115 61-64.

Kovacs K 1985 Light and electron microscopic pathology of pituitary tumors: immunocytochemistry. In Secretory Tumors of the Pituitary Gland, pp 365-376. Eds PM Black, NT Zervas, EC Ridgway \& JB Martin. New York: Raven Press.

Kovacs K \& Horvath E 1988 Pathology of pituitary adenomas. In Clinical Neuroendocrinology, pp 333. Eds R Collu, GM Brown \& GR Van-Loon. Boston: Blackwell.

Kovacs K, Horvath E, Ryan N \& Ezrin C 1980 Null cell adenoma of the human pituitary. Virchows Archiv. A, Pathological Anatomy and Histology 387 165-174.
Levy A, Hall L, Yeudall WA \& Lightman SL 1994 p53 gene mutations in pituitary adenomas: rare events. Clinical Endocrinology 41 809-814.

Lloyd RV, Jin L, Fields K \& Kulig E 1991 Effects of estrogens on pituitary cell and pituitary tumor growth. Pathology, Research and Practice 187 584-586 (Review).

Lyons J, Landis CA, Harsh G, Vallar L, Grunewald K, Feichtinger H, Duh QY, Clark OH, Kawasaki E \& Bourne HR 1990 Two G protein oncogenes in human endocrine tumors. Science $\mathbf{2 4 9}$ 655-659.

MacFarlane IA, Beardwell CG, Shalet SM, Ainslie G \& Rankin E 1982 Glycoprotein hormone alpha-subunit secretion in patients with pituitary adenomas: influence of TRH, LRH and bromocriptine. Acta Endocrinologica 99 487-492.

Mansour SJ, Matten WT, Hermann AS, Candia JM, Rong S, Fukasawa K, Vande Woude GF \& Ahn NG 1994 Transformation of mammalian cells by constitutively active MAP kinase kinase. Science 265 966-970.

Masters SB, Landis CA \& Bourne HR 1990 GTPase-inhibiting mutations in the alpha subunit of Gs. Advances in Second Messenger and Phosphoprotein Research 24 70-75 (Review).

Mathews LS 1994 Activin receptors and cellular signaling by the receptor serine kinase family. Endocrine Reviews 15 310-325.

Miller GM, Alexander JM, Bikkal HA, Katznelson L, Zervas NT \& Klibanski A 1995 Somatostatin receptor subtype gene expression in pituitary adenomas. Journal of Clinical Endocrinology and Metabolism 80 1386-1392.

Molitch ME 1987 Pathogenesis of pituitary tumors. Endocrinology and Metabolism Clinics of North America 16 503-527 (Review).

Montminy M 1993 Trying on a new pair of SH2 s [comment]. Science 261 1694-1695.

Murabe H, Shimatsu A, Ihara C, Mizuta H, Nakamura Y, Nagata I, Kikuchi H \& Nakao K 1996 Expression of somatostatin receptor (SSTR) subtypes in pituitary adenomas: quantitative analysis of SSTR 2 mRNA by reverse transcription-polymerase chain reaction. Journal of Neuroendocrinology 8 605-610.

Nakao H, Koga M, Arao M, Nakao M, Sato B, Kishimoto S, Saitoh Y, Arita N \& Mori S 1989 Enzyme-immunoassay for estrogen receptors in human pituitary adenomas. Acta Endocrinologica 120 233-238.

Panetta R \& Patel YC 1995 Expression of mRNA for all five human somatostatin receptors (hSSTR1-5) in pituitary tumors. Life Sciences 56 333-342.

Pearce SH, Trump D, Wooding C, Sheppard MN, Clayton RN \& Thakker RV 1996 Loss of heterozygosity studies at the retinoblastoma and breast cancer susceptibility (BRCA2) loci in pituitary, parathyroid, pancreatic and carcinoid tumours. Clinical Endocrinology 45 195-200.

Pei L \& Melmed S 1997 Isolation and characterization of a pituitary tumor-specific transforming gene. Molecular Endocrinology 11 433-441.

Pei L, Melmed S, Scheithauer B, Kovacs K, Benedict WF \& Prager D 1995 Frequent loss of heterozygosity at the retinoblastoma susceptibility gene (RB) locus in aggressive pituitary tumors: evidence for a chromosome 13 tumor suppressor gene other than RB. Cancer Research 55 1613-1616.

Roberson MS, Misra-Press A, Laurance ME, Stork PJ \& Maurer RA 1995 A role for mitogen-activated protein kinase in mediating activation of the glycoprotein hormone alpha-subunit promoter by gonadotropin-releasing hormone. Molecular and Cellular Biology $\mathbf{1 5}$ 3531-3539.

Sakamoto H, Mori M, Taira M, Yoshida T, Matsukawa S, Shimizu K, Sekiguchi M, Terada M \& Sugimura T 1986 Transforming gene from human stomach cancers and a noncancerous portion of stomach mucosa. Proceedings of the National Academy of Sciences of the USA 83 3997-4001. 
Samuels MH \& Ridgway EC 1995 Glycoprotein-secreting pituitary adenomas. Baillières Clinical Endocrinology and Metabolism 9 337-358 (Review)

Sano T, Asa SL \& Kovacs K 1988 Growth hormone-releasing hormone-producing tumors: clinical, biochemical, and morphological manifestations. Endocrine Reviews 9 357-373 (Review).

Scheithauer BW, Horvath E, Kovacs K, Laws E Jr, Randall RV \& Ryan N 1986 Plurihormonal pituitary adenomas. Seminars in Diagnostic Pathology 3 69-82.

Shimon I \& Melmed S 1997 Pituitary tumor pathogenesis. Journal of Clinical Endocrinology and Metabolism 82 1675-1681.

Shimon I, Huttner A, Said J, Spirina OM \& Melmed S 1996 Heparin-binding secretory transforming gene (hst) facilitates rat lactotrope cell tumorigenesis and induces prolactin gene transcription. Journal of Clinical Investigation 97 187-195.

Shupnik MA, Gharib SD \& Chin WW 1989 Divergent effects of estradiol on gonadotropin gene transcription in pituitary fragments. Molecular Endocrinology 3 474-480.

Snyder PJ 1985 Gonadotroph cell adenomas of the pituitary. Endocrine Reviews 6 552-563 (Review).

Snyder PJ, Bigdeli H, Gardner DF, Mihailovic V, Rudenstein RS, Sterling FH \& Utiger RD 1979 Gonadal function in fifty men with untreated pituitary adenomas. Journal of Clinical Endocrinology and Metabolism 48 309-314.

Snyder PJ, Bashey HM, Kim SU \& Chappel SC 1984 Secretion of uncombined subunits of luteinizing hormone by gonadotroph cell adenomas. Journal of Clinical Endocrinology and Metabolism 59 $1169-1175$.

Spada A, Arosio M, Bochicchio D, Bazzoni N, Vallar L, Bassetti M \& Faglia G 1990 Clinical, biochemical, and morphological correlates in patients bearing growth hormone-secreting pituitary tumors with or without constitutively active adenylyl cyclase. Journal of Clinical Endocrinology and Metabolism 71 1421-1426.

Stefaneanu L, Kovacs K, Horvath E, Lloyd RV, Buchfelder M, Fahlbusch R \& Smyth H 1994 In situ hybridization study of estrogen receptor messenger ribonucleic acid in human adenohypophysial cells and pituitary adenomas. Journal of Clinical Endocrinology and Metabolism 78 83-88.

Stenzel-Poore MP, Cameron VA, Vaughan J, Sawchenko PE \& Vale W 1992 Development of Cushing's syndrome in corticotropin-releasing factor transgenic mice. Endocrinology 130 $3378-3386$.

Strahl BD, Huang HJ, Pedersen NR, Wu JC, Ghosh BR \& Miller WL 1997 Two proximal activating protein-1-binding sites are sufficient to stimulate transcription of the ovine follicle-stimulating hormone-beta gene. Endocrinology 138 2621-2631.

Struthers RS, Vale WW, Arias C, Sawchenko PE \& Montminy MR 1991 Somatotroph hypoplasia and dwarfism in transgenic mice expressing a non-phosphorylatable CREB mutant. Nature 350 622-624.

Takino H, Herman V, Weiss M \& Melmed S 1995 Purine-binding factor (nm23) gene expression in pituitary tumors: marker of adenoma invasiveness. Journal of Clinical Endocrinology and Metabolism $801733-1738$

Thapar K, Kovacs K \& Muller PJ 1995 Clinical-pathological correlations of pituitary tumours. Baillières Clinical Endocrinology and Metabolism 9 243-270 (Review).

Tordjman K, Stern N, Ouaknine G, Yossiphov Y, Razon N, Nordenskjold M \& Friedman E 1993 Activating mutations of the Gs alpha-gene in nonfunctioning pituitary tumors. Journal of Clinical Endocrinology and Metabolism 77 765-769.

Warnet A, Porsova-Dutoit I, Lahlou N, Seret-Begue D, Lajeunie E, Chanson P, Woimant F, Lot G, Guillausseau PJ \& Roger M 1994 Glycoprotein hormone-alpha-subunit secretion in prolactinomas and in non-functioning adenomas: relation with the tumour size. Clinical Endocrinology 41 177-184.

Wehrenberg WB, Bloch B \& Phillips BJ 1984 Antibodies to growth hormone-releasing factor inhibit somatic growth. Endocrinology 115 1218-1220.

Weinberg RA 1995 The retinoblastoma protein and cell cycle control. Cell 81 323-330.

Weiss RE \& Refetoff S 1996 Effect of thyroid hormone on growth. Lessons from the syndrome of resistance to thyroid hormone. Endocrinology and Metabolism Clinics of North America 25 719-730 (Review).

Williamson EA, Daniels M, Foster S, Kelly WF, Kendall-Taylor P \& Harris PE 1994 Gs alpha and Gi2 alpha mutations in clinically non-functioning pituitary tumours. Clinical Endocrinology 41 815-820.

Woloschak M, Roberts JL \& Post KD 1994 Loss of heterozygosity at the retinoblastoma locus in human pituitary tumors. Cancer $\mathbf{7 4}$ 693-696.

Woloschak M, Yu A, Xiao J \& Post KD 1996 Frequent loss of the P16INK4a gene product in human pituitary tumors. Cancer Research 56 2493-2496.

Zafar M, Ezzat S, Ramyar L, Pan N, Smyth HS \& Asa SL 1995 Cell-specific expression of estrogen receptor in the human pituitary and its adenomas. Journal of Clinical Endocrinology and Metabolism 80 $3621-3627$.

Zumkeller W \& Schofield PN 1995 Growth factors, cytokines and soluble forms of receptor molecules in cancer patients. Anticancer Research 15 343-348 (Review).

Received 29 September 1997

Accepted 10 November 1997 